\title{
Planning and Policy of Renewable Energy Utilization in a Rural Economic Development Zone
}

\author{
Caiqing Zhang, Yilin $\mathrm{Xu}$ * \\ School of Economic Management, North China Electric Power University, BeishiDist, Baoding, China
}

Received: 31 October 2019

Accepted: 1 December 2019

\begin{abstract}
Renewable energy development is a dire need due to the energy shortage and environmental pollution in rural areas. It has a profound impact on rural construction and development by promoting the utilization of rural renewable energy. This paper puts forward the estimation method of rural renewable energy resources and generating capacity, making the maximum use of renewable energy and giving valuable policy suggestions for rural economic development zones. Taking the rural economic development zone of Jize County, Handan City, Hebei Province as an example, this paper analyzes the development status of the rural economic development zone. The results show that the renewable energy system with multiple complementary energy sources can meet the future energy demands of the development zone and generate 357.22 million $\mathrm{kWh}$ of electricity, which has certain environmental and social benefits. As to ensuring the project operation, some government policy suggestions are given at the end of this paper from the five aspects, i.e., finance, roof renovation, land use, capital investment and positive guidance. The renewable energy calculation methods and government policy suggestions proposed in this paper can be applied to the renewable energy planning of rural economic development zones all over the world.
\end{abstract}

Keywords: rural economic development zone, renewable energy, energy planning, government policy

\section{Introduction}

The development potential of rural renewable energy is huge [1]. There are abundant renewable energy sources such as solar, wind and biomass energy in rural areas. Through rational planning, the problem of resource scarcity can be alleviated while protecting the environment [2]. The reasonable development of

*e-mail: xuyilinada@126.com renewable energy is the most effective way to reduce carbon dioxide emissions and solve the increasingly serious energy and environmental problems. Zhang et al. discussed the application of five kinds of renewable energy in China, such as solar energy and wind energy, and put forward effective sequestration and conversion of carbon dioxide, which were of great significance to solve the environmental problems caused by excessive carbon dioxide emissions [3]. Moreover, renewable energy also provides a significant driving force for social, political and economic development, and plays a crucial role in ensuring energy security, improving 
environmental protection and increasing employment of all countries in the world [4]. Countries attach great importance to the green and low-carbon development of rural energy, which is a crucial part of promoting the energy revolution. The energy potential contained in organic waste from agriculture is significantly large from farms in the province of Warmia and Mazury in Poland, but it is disregarded by farmers and decisionmakers, and the level of renewable energy generated only from organic waste makes the idea of energy selfsufficiency of farms appear plausible [5]. However, only an organic combination of different aspects can bring about energy autarky of rural areas. The potential of renewable energy was assessed in the municipality of Nowa Słupia in Świętokrzyskie Voivodeship, Poland. It was indicated that the power generation of renewable energy had great potential, but it was also limited by some conditions, such as storage system, climate change and financial organization [6]. In Pakistan, the problem of power shortage and municipal solid waste treatment is in urgent need of solution. Waste incineration, a renewable energy generation method, not only meets the power demand, but also reduces environmental pollution [7]. By studying the application of renewable energy in China, it is concluded that the development and utilization of renewable energy is the most effective way to solve the increasingly serious energy and environmental problems, and it can be an important way to deal with the challenges of energy security and climate change [8]. In the planning and design of a hybrid renewable energy system, there are usually many objectives to be considered, so it is necessary to coordinate each objective so that all kinds of energy can better complement mutually [9]. The combination of ant colony algorithm, artificial immune system algorithm, etc. with model and software can improve the applicability of renewable energy system significantly, which is of great significance to the research of renewable energy [10].

Solar photovoltaic cells are widely used in various countries with their green, clean and lowcost characteristics. Combined with the distributed characteristics of solar power generation and the wide range of rural areas, solar photovoltaic power generation can be better applied to rural areas, which has a positive significance for developing the photovoltaic industry and optimizing a rural economy [11]. It has multiple benefits and functions to construct distributed photovoltaic power generation systems in accordance with large roof area in rural areas. It can make full use of solar energy to generate electricity and make it cleaner and more environmentally friendly [12]. However, the output of solar power generation is affected by some factors, such as the electrical parameters of a system itself, irradiance, weather conditions, temperature, season and so on [13]. Some scholars have done much research on solar irradiation on inclined surfaces, and put forward various models, such as the Liu-Jordan classic model [14], the Koronakis model [15] with variable coefficients, the Hay model [16] with more complex calculation methods, and the Ma-Iqbal model [17], etc. Since then, researchers have made comparative studies or improvements to various models. Hu used the Liu Jordan, Hay, Reindl and $\mathrm{K}+\mathrm{T}$ models to predict the solar irradiation value of a vertical wall and combined it with field radiation data so that the influence of different installation methods on solar radiation absorption on a photovoltaic surface was analyzed in detail [18]. In order to solve the problem of replacing electricity with coal in rural areas of the Beijing, Tianjin and Hebei region in China, individuals used distributed photovoltaic power generation to alleviate this problem, and analyzed a typical case of a family in a rural area. Through economic benefits analysis, it is found that this method not only reduces the cost of heating, but also produces good environmental benefits [19].

Rural areas are rich in wind energy resources, and the available wind energy potential is significant [20]. Generally, the mathematical models used to fit the wind speed distribution are Rayleigh distribution [21] and Weibull distribution [22], among which Weibull distribution is widely used in wind energy calculation. The energy of wind, affected by weather, climate and topography, is unstable. There was consistency of wind energy development with the process of sustainable planning and space management, that is, wind energy development had a certain impact on the spatial development of villages and towns. Malczyk proposed to create a common space to solve such problems, so that the development of the wind power industry would not impede spatial development [23]. Gugliani et al. put forward a new evaluating wind resources method: the modified energy pattern factor (MEPF) method. The authors compared this method with six common methods, and concluded that the MEPF method provided more accurate results [24]. Liu Fa et al. used the most complete wind speed data in China combined with a large-scale wind speed observation network to create wind resources temporal and spatial distribution for evaluation, and determined the characteristics of wind energy and the areas suitable for power generation [25].

Biomass power generation is mainly divided into three types: agricultural and forestry biomass power generation, garbage power generation and biogas power generation [26]. Nowadays, many scholars have studied the power generation potential of biomass resources in rural areas. Zuberi et al. conducted a study on biomass power generation in rural areas of Pakistan. The results showed that if the rural biomass resources can be fully used for power generation, it will not only reduce oil and natural gas import and carbon emissions, but also relieve the socio-economic pressure, and the conclusion could be applied to other developing countries with similar resources [27]. Using biogas instead of natural gas as the fuel of heating or energy system (although waste recovery cost was higher than energy saving cost), livestock 
manure was converted into high-quality fertilizer after fermentation, which had great environmental benefits [28]. Zhu et al. predicted the biomass energy of main crops in 2050 under low, medium and high field return ratios, and concluded that the biomass energy of the main crops in these three conditions is equivalent to the standard coal power generation of 186,93 and 15 million tons [29]. Malaysia's municipal solid waste contained high putrescible waste, which was transformed from landfills to organic bio power generation. It extended the life of the landfill, reduced the excessive dependence on non-renewable fossil fuels and improved the implementation of an alternative fuel plan [30]. When Zhang et al. estimated the biogas potential of poultry excrement resources, they first determined the main estimation parameters by consulting the literature, and then put forward the calculation methods of poultry excrement emissions, pollutant content and biogas potential estimation [31]. In addition, there are many related literatures on the coefficient of animal waste discharge [32-33]. The biogas project had good environmental benefits and power generation potential; nevertheless, its economic benefits were not significant. Boysan et al. studied the biogas power generation and economic benefits of a 100-cow farm. The biogas project brought a certain monthly income to the farm, but the amortization period was too long. Therefore, the biogas project needed the economic support of the government in order to obtain better economic benefits [34].

This paper analyzed the energy planning of a rural economic development zone, introduced the calculation method of renewable energy generation, determined the energy planning and utilization scheme, and applied it to the Jize County economic development zone to build a clean energy source system of renewable energy generation with multiple complementary energy sources. Furthermore, policy suggestions were put forward for the construction of such projects, which is of great significance for the energy planning of similar rural zones in the future.

\section{Methodology}

On the basis of characteristics of rural areas and considering actual factors, this paper came up with a method for calculating the power generation of solar energy, wind energy and biomass energy in rural areas. According to the calculated resources, a multi-energy complementary renewable energy system is planned to meet the power supply demand.

\section{Solar Power Generation Calculation Method}

In rural areas, solar energy can be absorbed over a large area by installing solar panels on the roofs of available residents. The rural solar energy resources can be calculated by estimating the total irradiation on photovoltaic panels, determining the photoelectric conversion and the actual power generation efficiency, and then the development potential of distributed photovoltaic can be obtained. The calculation of photovoltaic power generation is:

$$
P_{S}=S \times \eta_{1} \times \eta_{2} \times Q_{S}
$$

...where $P_{S}$ indicates solar power capacity, $S$ denotes total area of solar photovoltaic cells, $\eta_{1}$ and $\eta_{2}$ are photoelectric conversion efficiency and actual power generation efficiency of solar energy resources respectively, and $Q_{S}$ shows total irradiation on the inclined surface.

Firstly, the total irradiation on the inclined surface of solar photovoltaic panels should be calculated. The data obtained from the weather station is the amount of solar irradiation on the horizontal plane, so it is necessary to convert it into the irradiation on the inclined plane of photovoltaic array for the next generation calculation. Assuming that the scattering and ground reflection are isotropic, the calculation formula of the total solar exposure of an inclined moon is as follows according to the international practice and the calculation method of Klein [35]:

$$
\begin{gathered}
Q_{S}=D_{S}+S_{S}+F_{S} \\
D_{S}=D_{H} \cdot F_{b} \\
S_{S}=S_{H} \cdot\left(\frac{1+\cos \beta}{2}\right) \\
F_{S}=Q_{H} \cdot\left(\frac{1-\cos \beta}{2}\right) \cdot \theta \\
F_{b}=\frac{\cos (\varphi-\beta) \cdot \cos \delta \cdot \sin \omega+\frac{\pi}{180} \omega \cdot \sin (\varphi-\beta) \cdot \sin \delta}{\cos \varphi \cdot \cos \delta \cdot \sin \omega+\frac{\pi}{180} \omega \cdot \sin \varphi \cdot \sin \delta}
\end{gathered}
$$

$\omega=\min \left[\cos ^{-1}(\tan \varphi \cdot \tan \delta), \cos ^{-1}(-\tan (\varphi-\beta) \cdot \tan \delta)\right]$

...where $D_{S}$ is direct irradiation on the inclined surface, $S_{S}$ is scattering irradiation on the inclined surface, $F_{S}$ is reflective irradiation monthly exposure on the inclined surface, $D_{H}$ is horizontal planes direct irradiation, $F_{b}$ shows monthly average of the ratio of direct sun irradiation exposure of inclined surface to horizontal plane, $S_{H}$ indicates total horizontal irradiation, $\varphi$ shows latitude of the site, $\beta$ denotes the angle between the inclined surface and the horizontal plane, $\delta$ is solar declination in a representative day of each month, $\theta$ is 
Table 1. Selection of monthly representative days and its declination angle.

\begin{tabular}{|c|c|c|c|}
\hline Month & Representative day & $\begin{array}{c}\text { n (Date serial number) } \\
(\text { common year/leap year })\end{array}$ & $\begin{array}{c}\delta\left(^{\circ}\right) \\
(\text { common year/leap year) }\end{array}$ \\
\hline January & $17^{\text {th }}$ & 17 & -21.1 \\
\hline February & $16^{\text {th }}$ & 47 & -13.0 \\
\hline March & $16^{\text {th }}$ & $75 / 76$ & $-2.5 /-2.1$ \\
\hline April & $15^{\text {th }}$ & $105 / 106$ & $9.1 / 9.5$ \\
\hline May & $15^{\text {th }}$ & $135 / 136$ & $18.4 / 18.7$ \\
\hline June & $11^{\text {th }}$ & $162 / 163$ & $22.9 / 23.0$ \\
\hline July & $17^{\text {th }}$ & $198 / 199$ & $21.5 / 21.3$ \\
\hline August & $16^{\text {th }}$ & $228 / 229$ & $14.3 / 14.0$ \\
\hline September & $15^{\text {th }}$ & $258 / 259$ & $3.7 / 3.3$ \\
\hline October & $15^{\text {th }}$ & $288 / 289$ & $-7.8 /-8.2$ \\
\hline November & $14^{\text {th }}$ & $318 / 319$ & $-17.8 /-18.0$ \\
\hline December & $10^{\text {th }}$ & $344 / 345$ & $-22.7 /-22.8$ \\
\hline
\end{tabular}

monthly mean surface albedo, and $\omega$ is sunset time in representative day on each month.

The selection of representative dates for each month is shown in Table 1, and the surface albedo of typical underlying surfaces is shown in Table 2.

Through the above formulas, the monthly average irradiation in a certain area can be calculated directly. Secondly, the photoelectric conversion efficiency of solar panels should be determined:

$$
\eta_{1}=\frac{V_{o} \cdot I_{s} \cdot F_{f}}{S \cdot Q_{S}} \times 100 \%
$$

... where $V_{o}$ is open circuit voltage, $I_{S}$ is short circuit current, $F_{f}$ is fill factor.

The main factors affecting actual solar power generation efficiency are output deviation, efficiency

Table 2. Surface albedo of typical underlying surfaces.

\begin{tabular}{|c|c|}
\hline Underlying surface & $\begin{array}{c}\text { Surface albedo } \\
(\%)\end{array}$ \\
\hline Bare area & $10 \sim 25$ \\
\hline Desert & $25 \sim 46$ \\
\hline Grassland & $15 \sim 25$ \\
\hline Forest & $10 \sim 20$ \\
\hline Snow (compacted and clean) & $75 \sim 95$ \\
\hline Snow (wet and dirty) & $25 \sim 75$ \\
\hline Sea surface (solar elevation angle $>25^{\circ}$ ) & $<10$ \\
\hline Sea surface (solar elevation angle $<25^{\circ}$ ) & $10 \sim 70$ \\
\hline
\end{tabular}

Note: This table is quoted from Dictionary of Atmospheric Science. reduction caused by dust shielding, non-uniform solar irradiation and imbalance caused by fixed installation angle, etc. Therefore, the actual solar power generation efficiency should be determined according to the actual situation of each project, and the product of each factor is the actual power generation efficiency:

$$
\eta_{2}=\prod_{i=1}^{n} \mu_{i}
$$

...where $\mu_{i}$ indicates influence coefficient of factor $i$ on solar power generation.

\section{Wind Power Generation Calculation Method}

According to the discontinuity of the distribution of rural wind resources and the scarcity of land resources, distributed wind power generation is a better way to make full use of wind resources. For a certain wind turbine, power generation can be calculated according to the local wind energy situation. Firstly, the power generation of a single wind turbine is calculated, then the number of wind turbines is determined according to the available land resources in the region, and finally the wind power generation in the region is calculated. The calculation formula of power generated by a single wind turbine is as follows:

$$
\overline{P_{w t}}=\frac{1}{2} \rho \pi r^{2} v^{3} C_{P}
$$

...where $\overline{P_{w t}}$ is power generation of a single wind turbine, $\rho$ is air density, $r$ is blade radius of the wind turbine, $v$ is rated wind speed, and $C_{P}$ is wind turbine airfoils. 
The calculation of air density is as follows.

$$
\rho=\frac{1.276}{1+0.00366 t}\left(\frac{P-0.378 e}{1000}\right)
$$

According to Betz' Law [36], the limit ratio of wind energy to kinetic energy under ideal conditions is $16 / 27$, so the maximum value of CP is about $59 \%$.

In the practical application of wind power generation, there are many factors affecting its power generation, including control and turbulence reduction, blade pollution reduction, wind turbine availability, climate factors and so on. Therefore, the actual efficiency of wind power generation is the product of influencing factors:

$$
P_{w t}=\overline{P_{w t}} \cdot T \prod_{i=1}^{n} \gamma_{i}
$$

...where $P_{w t}$ is generation capacity of a single wind turbine, $T$ is effective hours of wind power generation, and $\gamma_{i}$ is various influencing factors of actual wind power generation.

According to the calculated generation of a single wind turbine, the wind power generation in the area can be calculated:

$$
P_{w}=P_{w t} \times N_{w}
$$

$\ldots$ where $P_{w}$ is wind power generation in the area and $N_{w}$ is quantity of wind turbines.

The quantity of wind turbines is determined by the availability of land resources in the region and the coverage area of a single wind turbine:

$$
N_{w}=\frac{S_{l w}}{S_{w}}
$$

...where $S_{l w}$ is available land area and $S_{w}$ is the coverage area of a single wind turbine.

\section{Biomass Power Generation Calculation Method}

The biomass energy resources considered in this paper mainly include straw direct combustion and biogas power generation. According to the different crop straw grain rate and different straw dry matter gas production, the straw resources and methane production in this area can be calculated:

$$
\begin{aligned}
& R_{S}=\sum_{i=1}^{n} \sigma_{i} \times Y_{c i} \\
& R_{S}^{\prime}=R_{S} \times c_{s} \times r_{s e}
\end{aligned}
$$

$$
B_{S}=\sum_{i=1}^{n} b_{i} \times R_{S}^{\prime}
$$

...where $R_{S}$ indicates resources of straw, $\sigma_{i}$ represents the straw-grain ratio of various crops, $Y_{c i}$ is crop yield, $R_{S}^{\prime}$ means the amount of straw resources that can be used as energy, $c_{s}$ is recovery coefficient of straw, $r_{s e}$ is energy ratio of straw, $B_{S}$ is biogas production from straw, and $b_{i}$ is biogas production rate.

On the basis of the excretion coefficient and gas production rate of poultry excrement, the resource and methane production amount of poultry excrement can be worked out:

$$
B_{p}=\sum_{i=1}^{n} e_{i} \times d_{i} \times a_{i}
$$

...where $B_{p}$ means biogas production from poultry excrement, $e_{i}$ is the amount of poultry excrement, $d_{i}$ is dry matter content coefficient of poultry excrement, and $a_{i}$ is biogas production rate of poultry excrement.

Rural biogas is mainly produced by straw fermentation and poultry excrement fermentation; direct combustion is mainly straw combustion. Therefore, the calculation formula of rural biomass power generation is as follows:

$$
P_{g b}=R_{S}^{\prime} \times c \times P_{g c}+P_{g b g} \times \sum_{i=1}^{n} B_{i}
$$

...where $P_{g b}$ means electricity generation of biomass, $c$ is folding factor, and $P_{g c}$ and $P_{g b g}$ represent electricity generation of standard coal and biogas respectively.

\section{Results and Discussion}

Based on the calculation method of renewable energy power generation, this paper gives a detailed example analysis. Jize industrial economic development zone studied in this paper is located at the junction of Shanxi, Hebei, Shandong and Henna provinces. It is the intersection of the Capital Economic Zone, Shandong Peninsula Blue Economic Zone and the Central Plains Economic Zone. Located in northeast Handan City, Hebei Province, China, Jize County is a typical plain agricultural county with longitude of 114.87 degrees and latitude of 36.92 degrees. The zone consists of four major parks with a total land area of $17.69 \mathrm{~km}^{2}$ and construction land area of $14.27 \mathrm{~km}^{2}$.

At present, three $360 \mathrm{MW}$ main transformers of Handan Power Company are used to supply power to all enterprises in the park. In terms of the 2030 plan of the Jize Zone, energy demand is diversified. Represented by the casting park, the cancellation of self-supplied coal-fired power generating units leads to a sharp increase in the power gap, which directly affects 
Table 3. Irradiation data tables of Jize County.

\begin{tabular}{|c|c|c|}
\hline Month & $\begin{array}{c}\text { Horizontal planes } \\
\text { directly irradiation }\end{array}$ & $\begin{array}{c}\text { Horizontal planes } \\
\text { scattering irradiation }\end{array}$ \\
\hline January & 66.9 & 40.6 \\
\hline February & 79.3 & 47.4 \\
\hline March & 113.9 & 69.6 \\
\hline April & 135.2 & 83.4 \\
\hline May & 168.6 & 101.7 \\
\hline June & 161.3 & 99.5 \\
\hline July & 147.4 & 93.7 \\
\hline August & 140.2 & 89.8 \\
\hline September & 115.5 & 65.3 \\
\hline October & 96.1 & 55.0 \\
\hline November & 72.0 & 38.3 \\
\hline December & 60.2 & 35.2 \\
\hline
\end{tabular}

Note: Data in the table are from Meteonorm 7.1

the normal operation of enterprises in the park. Park officials estimate an annual power gap of 140 million degrees. Using renewable energy to generate electricity not only fills the power gap of the zone, but also meets the energy demand of the surrounding rural areas.

\section{Results of Renewable Energy Generation in the Zone and Surrounding Areas}

\section{Solar Power Generation}

The photovoltaic power generation in this zone is mainly based on the roofs of houses and factories, and adopts a fixed operation mode. The solar panels are designed to face due south with an optimum fixed inclination of 36 degrees. Considering the efficiency, technological maturity and market share of components, it is recommended to select polysilicon components in this zone.

A total of 60 polysilicon photovoltaic modules were selected in this area. Table 4 shows the photoelectric conversion efficiency of modules of different specifications.

$280 \mathrm{Wp}$ polycrystalline panels with photoelectric conversion efficiency of $17.1 \%$ and single board area of $1.6368 \mathrm{~m}^{2}$ were selected in this zone. The total solar irradiation of batteries in the zone is about $1490.4 \mathrm{kWh} / \mathrm{m}^{2}$ (Table 5). The available roof area of the park is $248,000 \mathrm{~m}^{2}$, which can accommodate 151,515 polycrystalline panels and install $42.42 \mathrm{MW}$ photovoltaic power generation capacity. If roofs of residential houses can be modified to meet solar panel installation standards and the residents agree to build photovoltaic projects on their roofs, the solar power generation capacity will be higher.

The actual solar power generation in this zone is affected by various factors, mainly the following three:

1) Output deviation

The DC power output from solar panels is nominal output power. The allowable deviation of the solar panel output in field is $5 \%$, and the influence factor of 0.95 should be taken into account when analyzing.

2) Solar cell module surface temperature

With the increase of solar cell module surface temperature, the output power decreases to $89 \%$ of the rated output power when the temperature reaches $50-75^{\circ} \mathrm{C}$. Therefore, the influence factor of 0.89 should be considered when analyzing.

3) Dust

In the case of dust accumulation on PV modules, the solar irradiation intensity on module surface will be affected, and then the output power will be affected [37]. The value is around $4 \%$, so the influence factor of 0.96 should be considered.

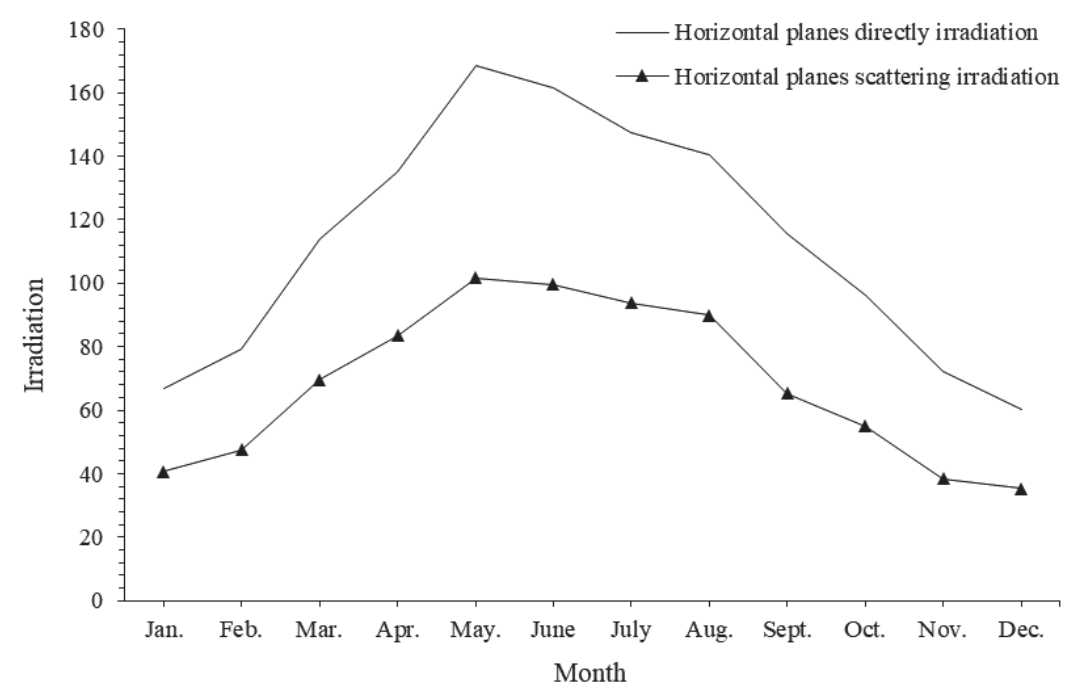

Fig. 1. Monthly average irradiation in Jize County. 
Table 4. Photoelectric conversion efficiency tables of 60 polycrystalline silicon photovoltaic modules with different specifications.

\begin{tabular}{|c|c|c|c|c|c|c|c|}
\hline Component type & $\begin{array}{c}\text { ECS- } \\
270 \mathrm{M} 60\end{array}$ & $\begin{array}{c}\text { ECS- } \\
275 \mathrm{M} 60\end{array}$ & $\begin{array}{c}\text { ECS- } \\
280 \mathrm{M} 60\end{array}$ & $\begin{array}{c}\text { ECS- } \\
285 \mathrm{M} 60\end{array}$ & $\begin{array}{c}\text { ECS- } \\
290 \mathrm{M} 60\end{array}$ & $\begin{array}{c}\text { ECS- } \\
295 \mathrm{M} 60\end{array}$ & $\begin{array}{c}\text { ECS- } \\
300 \mathrm{M} 60\end{array}$ \\
\hline Maximum power (Wp) & 270 & 275 & 280 & 285 & 290 & 295 & 300 \\
\hline Open-circuit voltage (V) & 38.5 & 38.9 & 39.3 & 39.8 & 40.2 & 40.6 & 41.0 \\
\hline Short-circuit current (A) & 9.35 & 9.43 & 9.50 & 9.55 & 9.62 & 9.75 & 9.83 \\
\hline Photoelectric conversion efficiency (\%) & 16.6 & 16.9 & 17.1 & 17.5 & 17.8 & 18.0 & 18.3 \\
\hline
\end{tabular}

Table 5. Total irradiation on polycrystalline panels in each month.

\begin{tabular}{|c|c|c|c|}
\hline Month & $\begin{array}{c}\text { Horizontal planes directly } \\
\text { irradiation }\end{array}$ & $\begin{array}{c}\text { Horizontal planes scattering } \\
\text { irradiation }\end{array}$ & $\begin{array}{c}\text { Total irradiation on polycrystalline } \\
\text { panels }\end{array}$ \\
\hline January & 66.9 & 40.6 & 103.3 \\
\hline February & 79.3 & 47.4 & 130.9 \\
\hline March & 113.9 & 69.6 & 138.6 \\
\hline April & 135.2 & 83.4 & 160.0 \\
\hline May & 168.6 & 101.7 & 145.9 \\
\hline June & 161.3 & 99.5 & 134.5 \\
\hline July & 147.4 & 93.7 & 126.6 \\
\hline August & 140.2 & 89.8 & 118.0 \\
\hline September & 115.5 & 65.3 & 104.4 \\
\hline October & 96.1 & 55.0 & 92.6 \\
\hline November & 72.0 & 38.3 & 1490.4 \\
\hline December & 60.2 & 35.2 & 819.6 \\
\hline Total & 1356.6 & 8 & \\
\hline
\end{tabular}

As a result, the actual power generation efficiency is $81.17 \%$. According to the formulas above, solar power generation capacity of the zone is 51.3 million degrees.

\section{Wind Power Generation}

The climate of Jize County is dry and windy in spring, hot and rainy in summer, clean and cool in autumn, cold and dry in winter, rich in wind energy resources, suitable for scattered wind power generation. Decentralized wind power is a wind power project located near the power load center. It is not designed for large-scale and long-distance transmission of electricity. It has the characteristics of near access, local absorption, small investment scale, short construction period and stable income. Decentralized wind power generation systems are mainly used in rural, pastoral, and mountainous areas, and in surrounding large, medium and small cities and commercial areas. The surplus land in and around the Jize zone can be developed into a decentralized wind power system. Table 6 describes the basic situation of wind power generation in Jize County.

The actual efficiency of wind power generation is also related to air density correction, control and turbulence reduction, climate impact, blade pollution, etc.

1) Air density correction

There is little difference between air density in wind farm area and standard air density. When calculating power generation, no correction for air density is made.

2) Control and turbulence reduction

Wind turbines control the state of the unit through changes in wind speed and direction. However, the

Table 6. Basic situation of wind power generation in Jize County.

\begin{tabular}{|c|c|}
\hline Index & Value \\
\hline Hub height $(\mathrm{m})$ & 120 \\
\hline Rotor diameter $(\mathrm{m})$ & 62 \\
\hline Cut-in speed $(\mathrm{m} / \mathrm{s})$ & 3 \\
\hline Rated wind speed $(\mathrm{m} / \mathrm{s})$ & 14 \\
\hline Cut-out speed $(\mathrm{m} / \mathrm{s})$ & 20 \\
\hline Wind turbine airfoils & 0.45 \\
\hline Density of air $\left(\mathrm{kg} / \mathrm{m}^{3}\right)$ & 1.215 \\
\hline
\end{tabular}


actual situation is that the unit operation control always lags behind the change of the wind, resulting in the loss of power generation. The main reason is that the entry lag of the wind turbine will cause a part of power generation loss, while the yaw system will cause power generation loss due to the change of wind direction. In general, the deceleration factor for control and turbulence is approximately $3 \%$.

3) Blade pollution

Pollution on the blade surface increases the surface roughness of the blade and decreases the aerodynamic characteristics of the airfoil, thus reducing power generation. On the basis of the actual situation in Jize County, the blade pollution coefficient is estimated to be $1 \%$.

4) Climate impact

The climate impact coefficient of Jize County is about $2 \%$, including the influence of low temperature, thunderstorm, hail, sandstorm and other severe weather on the power loss of a wind farm.

5) Power curve reduction

The guaranteed rate of wind turbine power curve is $95 \%$ by generator manufacturers. Therefore, the reduction factor of the wind turbine power curve is $5 \%$.

As a consequence, actual wind power generation efficiency is $89 \%$, and the scale of a single wind turbine can reach $2.2 \mathrm{MW}$ according to formulas above. A single wind turbine, $120 \mathrm{~m}$ high, covers an area of about $400 \mathrm{~m}^{2}$. Its annual utilization hours are 2582; thus, its annual power generation capacity is 5.2 million kilowatt-hours.

\section{Biomass Power Generation}

\section{1) Crop straw resource}

There are lots of wheat and corn planted in Jize County, and the planting status of various crops is shown in Table 7.

The straw-grain ratio of various crops [38] and the gas yields of different straw dry matter in China [39] are shown in Tables 8 and 9, respectively.

According to the formula, the relevant data of crop straw resources in Jize County can be worked out (Table 10).

Table 7. Production status of major agricultural products in Jize County.

\begin{tabular}{|c|c|c|c|}
\hline Crop & $\begin{array}{c}\text { Area } \\
(\mathrm{mu})\end{array}$ & $\begin{array}{c}\text { Yield per mu } \\
(\mathrm{kg} / \mathrm{mu})\end{array}$ & $\begin{array}{c}\text { Yield } \\
\text { (ton) }\end{array}$ \\
\hline Wheat & 255465 & 481 & 122879 \\
\hline Corn & 188015 & 467 & 84067 \\
\hline Peanut & 3510 & 225 & 789 \\
\hline Cotton & 26520 & 74.5 & 1976 \\
\hline Soybean & 1845 & 94.9 & 175 \\
\hline
\end{tabular}

Note: Data in this table are from Statistical Yearbook in Jize County.
Table 8. Straw-grain ratio of various crops in China.

\begin{tabular}{|c|c|}
\hline Crop & Straw-grain ratio \\
\hline Wheat & 1.718 \\
\hline Corn & 1.269 \\
\hline Peanut & 1.348 \\
\hline Cotton & 1.613 \\
\hline Soybean & 1.295 \\
\hline
\end{tabular}

Table 9. Gas production rate of different straw dry matter.

\begin{tabular}{|c|c|}
\hline Straw & Gas production rate $(\mathrm{ml} / \mathrm{g} / \mathrm{d})$ \\
\hline Wheat straw & 15.6 \\
\hline Corn straw & 12.3 \\
\hline Rice straw & 20.1 \\
\hline
\end{tabular}

Table 10. Crop straw resources in Jize County.

\begin{tabular}{|c|c|}
\hline Straw & Resource (ton) \\
\hline Wheat straw & 211000 \\
\hline Corn straw & 106000 \\
\hline Peanut straw & 1100 \\
\hline Cotton straw & 3200 \\
\hline Soybean straw & 200 \\
\hline Total & 321500 \\
\hline
\end{tabular}

The amount of straw resources available for energy utilization in Jize County is 1543000 tons in light of $80 \%$ recovery coefficient and $60 \%$ energy utilization ratio of straw.

2) Poultry excrement resource

According to the statistics of animal husbandry production in Jize County, 10300 cattle, 105200 pigs, 164400 sheep and 4035000 chickens are raised every year. Based on this, poultry excrement output is calculated in Table 11.

Poultry excrement resources and their biogas production can be estimated according to the excretion coefficient and gas production rate [40], thus it can be

Table 11. Annual poultry excrement in Jize County

\begin{tabular}{|c|c|}
\hline Species & Poultry excrement (ton) \\
\hline Pig & 199000 \\
\hline Cattle & 79000 \\
\hline Sheep & 143000 \\
\hline Chicken & 121000 \\
\hline
\end{tabular}


Table 12. Annual biogas production from poultry excrement in Jize County.

\begin{tabular}{|c|c|c|c|}
\hline Species & $\begin{array}{c}\text { Dry matter content ratio } \\
(\%)\end{array}$ & $\begin{array}{c}\text { Gas production rate } \\
\left(\mathrm{m}^{3} / \mathrm{kg}\right)\end{array}$ & $\begin{array}{c}\text { Biogas production } \\
\left(\mathrm{m}^{3}\right)\end{array}$ \\
\hline Pig & 20 & 0.2 & 7960000 \\
\hline Cattle & 18 & 0.3 & 4266000 \\
\hline Sheep & 75 & 0.15 & 16087500 \\
\hline Chicken & 80 & 0.05 & 4840000 \\
\hline
\end{tabular}

calculated that these poultry excrement resources can produce 33.153 million cubic meters of biogas per year.

\section{Multi-Energy Complementary Renewable Energy Project Planning}

According to the renewable energy resources and energy needs of the zone and surrounding areas, distributed solar power generation, decentralized wind power generation, biogas power generation and straw direct combustion power generation have been established to make full use of the roofs of buildings, land, crop straw and poultry excrement. It is also planned to rely on the grid to build a clean energy supply system with a high proportion of renewable energy power generation in the zone, and to promote biogas projects under the economic cooperation model of biogas-electric-biogas and fertilizers, while replacing the chemical fertilizers with biogas fertilizers to promote the development of green agriculture.

\section{Scale of Solar Power Generation Project}

In line with the principle of making full use of solar energy resources, $151515280 \mathrm{Wp}$ polycrystalline panels are planned to put into use with available roofs and construct $42.42 \mathrm{MW}$ photovoltaic power generation project in Jize zone. After completion and commissioning, the annual solar power generation is 51.3 million degrees.

\section{Scale of Decentralized Wind Power Generation Project}

According to Jize County land resources and distributed wind farm planning, the existing land resources of about $400 \mathrm{mu}$, namely 260,000 square meters. In the construction, $2.2 \mathrm{MW}$ wind turbines are selected, and 27 decentralized wind turbines can be planned and constructed. The installed wind power capacity is $60 \mathrm{MW}$, and the annual generating capacity of a single wind turbine is 5.2 million degrees. Therefore, the annual generating capacity of the wind power project in the economic development zone is 14.4 million degrees.

\section{Scale of Biogas-Electricity-Fertilizer Co-Production Biogas Power Generation Project}

Starting with the overall planning of biogaselectricity-fertilizer and the development of green agriculture, the scale of gas-electricity-fertilizer coproduction biogas power generation project is planned by the amount of poultry excrement and organic fertilizer replacing chemical fertilizer.

1) Determination of biogas project scale based on organic fertilizer demand

In the utilization of biogas fertilizer, about 1.5 tons of biogas residue, used as base fertilizer, and 1-1.5 tons of biogas slurry, used as topdressing

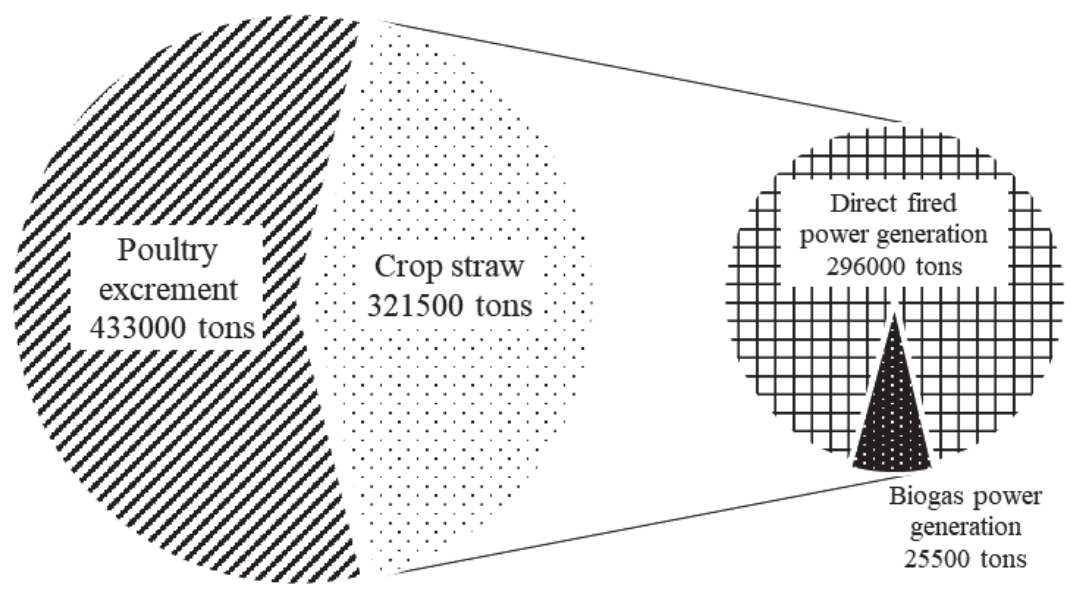

Fig. 2. Distribution of biomass resources in Jize County. 
fertilizer, are applied per mu of land. The production status of the main agricultural products in Jize County shows that the area used for grain crops and vegetables is $445650 \mathrm{mu}$ and $182160 \mathrm{mu}$, respectively. The organic agricultural land, calculated according to $80 \%$ of the area of these two kinds of land, is $502248 \mathrm{mu}$.

Assuming that all organic fertilizers used in agriculture are supplied by biogas fertilizers produced by biogas power generation projects, the annual demand for biogas slurry and residues is about 1.381 million tons. Accordingly, a biogas power generation project with an annual biogas output of 39.515 million $\mathrm{m}^{3}$ is needed.

2) Resource allocation of biogas project

Poultry excrement methane production in Jize County is 33.153 million $\mathrm{m}^{3}$. In order to meet the needs of green agriculture for organic fertilizer, $6360000 \mathrm{~m}^{3}$ of biogas needs to be built, so 25500 tons of corn straw are needed for biogas power generation.

In all, 433,000 tons of poultry excrement and 25,500 tons of straw were used to generate electricity from biogas. Biogas slurry and residue will be made into biogas fertilizer, meeting the requirements of agricultural fertilizer. The remaining straw is burned directly to generate electricity.

3) Scale of biogas power generation project

To produce 39.515 million $\mathrm{m}^{3}$ of biogas annually, $140000 \mathrm{~m}^{3}$ of biogas digester and six 1MW gasgenerating units need to be built. According to the commonly used anaerobic fermentation technology, the project requires seven fermentation equipment of $15,000 \mathrm{~m}^{3}$ scale. The biogas project has an annual generating capacity of 52.56 million $\mathrm{kWh}$. By processing biogas fertilizer production line, 13000 tons of fertilizer and 62000 tons of liquid fertilizer can be produced.

\section{Scale of Straw Direct Combustion Power Generation Project}

The amount of straw used for energy conversion is 321500 tons per year in Jize County, of which 25500 tons are used for biogas power generation project, and the remaining 296000 tons are used for straw direct combustion power generation project, which can build 60 MW straw direct combustion power generation project with an annual power generation capacity of 296 million degrees.

\section{General Planning for Renewable Energy Utilization in Economic Development Zone}

According to the calculation above, the generating capacity of renewable energy projects reaches 540.26 million degrees, which exceeds the total power consumption of the zone. It shows that Jize County is rich in renewable energy resources and has a good development potential. Considering the current financial condition and the power demand of the zone, the proposed scale of various energy generation installations for the multi-energy complementary renewable energy generation project is as follows.

1) The installed scale of solar power generation is $42.42 \mathrm{MW}$, with an average annual power generation capacity of 51.3 million degrees.

2) The installed scale of decentralized wind power generation is $60 \mathrm{MW}$, with annual power generation capacity of 140.4 million degrees.

3) The installed scale of biogas power generation is $2 \mathrm{MW}$, with annual power generation capacity 17.52 million degrees, 5300 tons solid fertilizer and 21600 tons liquid fertilizer.
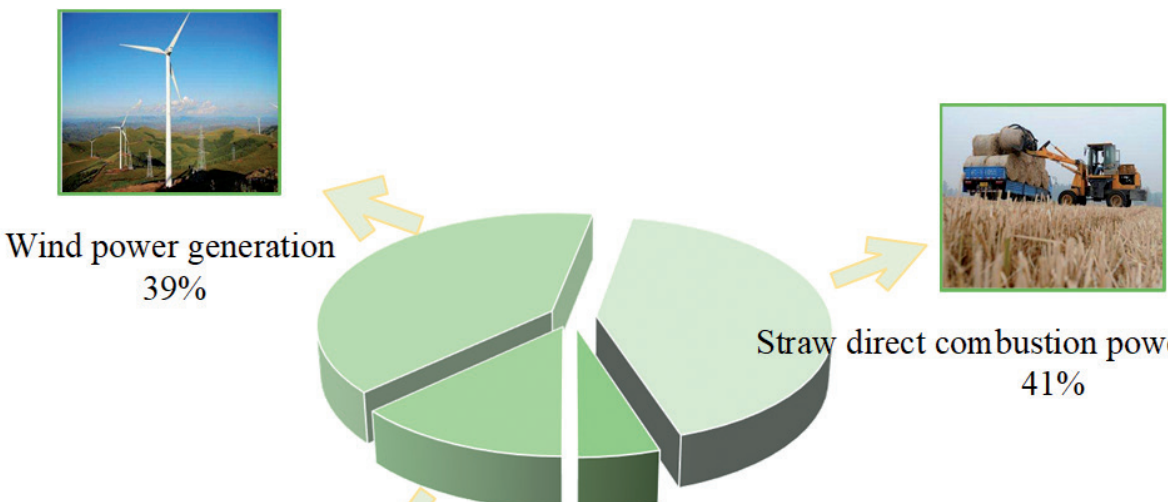
$39 \%$
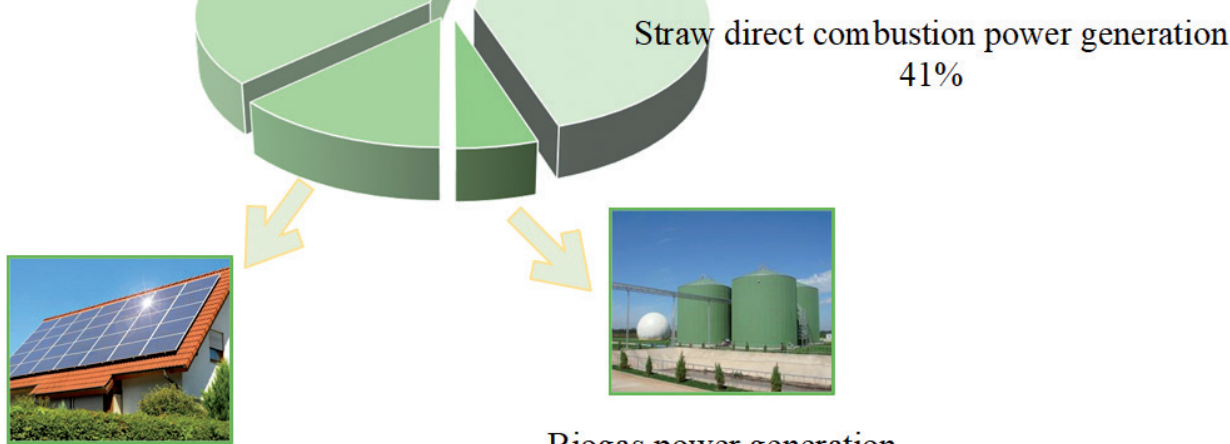

Solar power generation $14 \%$

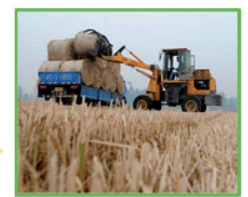

$41 \%$

Fig. 3. Scale of renewable energy power generation projects in the zone. 
4) The installed scale of straw direct combustion power generation is $30 \mathrm{MW}$, with annual power generation capacity of 148 million degrees.

The total installed power generation capacity is $149.42 \mathrm{MW}$, and the annual power generation capacity is 357.22 million degrees. This not only meets the energy demand of Jize County Rural Economic Development Zone in future planning, but also supplies energy to the surrounding areas and solves the energy demand of surrounding rural areas.

Through the implementation of this plan, straw and excrement are fully and effectively utilized for energy, which improves rural sanitation and the ecological environment, and is conducive to promoting the construction of beautiful countryside. Organic biogas fertilizer produced by the biogas project can replace chemical fertilizer, improve soil, promote organic green agriculture development and improve the economy of the biogas project, which forms a coordinated development of planting-breeding-power-organic agriculture.

Due to the complementarity of stable biogas and straw, direct combustion power generation and wind and solar power generation, this multi-energy complementary renewable energy coupling system can realize complementary wind, solar, biogas and straw direct combustion power generation, and form a reliable, economic and clean energy supply system.

\section{Government Policy Suggestion}

\section{1) Financial support}

The project involves comprehensive utilization of various energy resources with large investment and long cycle. The government is required to provide appropriate financial support policies to meet the needs of project construction and working capital, mainly in financing, subsidies, taxes and investment.

In the early stage of project investment, the government should simplify the loan procedures, simplify the process, and give preferential policies in terms of interest rates. Relying on government finance, the government participates in part of the project investment. On the one hand, it supports the construction of the project, and at the same time it has a certain share to control in the construction and operation of the project, so that the government can supervise and manage the project. Due to the non-subsidy policy of new energy power generation projects, the benefits of the project are faced with great risks; nevertheless, the project has huge social and environmental benefits. It should be given a certain subsidy and tax incentives according to the economic situation of projects.

2) Renovation of roofs

From the view of the roof structure in the zone, many of them do not meet the conditions needed for building a solar power generation system. If a largescale photovoltaic power generation system wants to be built, the existing roofs need to be reconstructed. The government should strongly promote roof renovation in conjunction with energy-saving building renovation, so that it meets the conditions for installing solar power generation systems.

3) Land use policy

Land resources restrict the development of decentralized wind power and biogas power generation projects. In order to ensure the construction of such projects, land use policies need to be introduced.

4) Encouraging social capital to participate in rural energy investment

Rural energy projects are heavily invested but underfunded. The introduction of social capital is an effective measure to solve the financial dilemma of rural energy development. On this basis, incentive policies that encourage social capital to participate in rural energy investment should be introduced. In addition to preferential policies on land use, finance, and taxation, the government should also provide highquality and efficient services in online project approval, construction, employment, operation and management to ensure the smooth implementation of the project.

5) Government's positive guide

Initially, the government should guide enterprises in the zone actively to use the clean energy provided by the project and sign long-term power purchase agreements with the project operators. Secondly, they should guide building owners of the building in the zone to carry out energy-saving building and roof structure renovation, and encourage enterprises to participate in rooftop solar power generation projects through roof leasing or roof sharing. Furthermore, they should actively guide the cultivation and consumption of organic green agricultural products and the use of organic biogas fertilizer to promote the development of organic agriculture and create better conditions for biogas power generation projects. Ultimately, the government should encourage farmers and project operators to sign long-term agreements on straw recycling in order to guide the use of straw energy, and ensure the sustainable development of straw direct-fired power generation projects.

\section{Conclusions}

This paper studies the utilization planning of renewable energy in a rural economic development zone. The calculation methods of solar energy, wind energy and biomass energy resources as well as their power generation are studied. Taking the economic development zone in Jize County, Handan City, Hebei Province, China, as an example, this paper estimates the renewable energy resources and power generation of this zone, and puts forward planning and policy suggestions. Compared with a traditional singleenergy supply system, a multi-energy complementary renewable energy system can meet the regional power gap and further energy needs. Furthermore, it can 
provide energy for the surrounding areas and solve the problem of energy shortages in rural areas that has plagued the government.

In addition to the calculation method of this kind of renewable energy planning for a rural economic development zone, this paper also puts forward relevant policy suggestions on the implementation of the multienergy complementary renewable energy system project. It shows that the implementation of the project can make full and effective use of waste resources, improve the rural environmental and ecological environment, and promote the development of organic green agriculture, with certain environmental and social benefits. Therefore, the government should introduce funds, roof renovation, land use, capital investment and active guiding policies to ensure the improvement and construction of renewable energy projects with multienergy complementary energy sources. The calculation methods and policy suggestions proposed in this paper are applicable to the planning of multi-energy complementary renewable energy in rural economic development zones.

\section{Acknowledgements}

The financial supports of the National Nature Science Foundation Project of China (No. 71471061) is gratefully acknowledged. The authors would like to thank Prof. Meng for improving the quality of this manuscript.

\section{Conflict of Interest}

The authors declare no conflict of interest.

\section{References}

1. WOCH F., HERNIK J., LINKE H.J., SANKOWSKI E., BĘCZKOWSKA M., NOSZCZYK T. Renewable Energy and Rural Autonomy: A Case Study with Generalizations. Polish Journal of Environmental Studies, 26 (6), 2823, 2017.

2. ZHANG L.X., HU Q.H., WANG C.B. Spatial-temporal Distribution Characteristics and Policy Evolution of Rural Energy Consumption in China. Journal of Agricultural Engineering, 27 (01), 1, 2011.

3. ZHANG K., SHEN J., ZHANG J., HAN H. Recent Advances on Renewable Energies and Carbon Capture. Polish Journal of Environmental Studies, 28 (4), 2541, 2019.

4. ZHANG M., ZHANG B. Development status and Prospect of renewable energy in the world. China electric power enterprise management, 19, 42, 2014.

5. BIERANOWSKI J, OLKOWSKI T. The Concept of an Energy Self-Suffi cient Farm System Compatible with Sustainable Development in a Selected Region in Poland. Polish Journal of Environmental Studies. 25 (2), 529, 2016.
6. WOCH F., HERNIK J., LINKE H.J., SANKOWSKI E., BECZZKOWSKA M., NOSZCZYK T. Renewable Energy and Rural Autonomy: A Case Study with Generalizations. Polish Journal of Environmental Studies, 26 (6), 2823, 2017.

7. SHAHZAD S., BUTT A., ANWAR S., AHMAD S.R., SARWAR T., ASGHAR N. Municipal Solid Waste as a Renewable Source of Energy: an Overview from the Lahore District in Punjab, Pakistan. Polish Journal of Environmental Studies. 26 (6), 2721, 2017.

8. ZHANG K., SHEN J., ZHANG J., HAN H. Recent Advances on Renewable Energies and Carbon Capture. Polish Journal of Environmental Studies. 28 (4), 2541, 2019.

9. ERDINC O., UZUNOGLU M. Optimum design of hybrid renewable energy systems: Overview of different approaches, Renewable and Sustainable Energy Reviews, 16 (3), 1412, 2012.

10. MING M.J., ZHANG T., WANG R., LIU Y.J., CHA Y.B. Review of multi-objective optimization of hybrid renewable energy system. Chinese Journal of electrical engineering, 38 (10), 2908, 2018.

11. LIU F., JU W., HAN X. Application and Promotion of Photovoltaic Power Generation in Rural Areas of China. Journal of Changchun Institute of Engineering, 19 (03), 44, 2018.

12. YUE X.H. Design and operation analysis of rural roof distributed photovoltaic power station. Communication power technology, 35 (09), 82, 2018.

13. WANG S.J., PING C., XUE G.B., WANG D.G., JIANG T. Research and analysis of factors affecting photovoltaic power output. Electrical Technology, 19 (08), 68, 2018.

14. LIU B.Y.H., JORDAN R.C. Daily insolation on surfaces tilted towards equator. ASHRAE Transactions, 67, 526, 1962.

15. KORONAKIS P.S. On the choice of the angle of tilt for south facing solar collectors in the Athens basin area. Solar Energy, 36 (3), 217, 1986.

16. HAY J.E. Calculation of monthly mean solar radiation for horizontal and inclined surfaces. Solar Energy, 23 (4), 301, 1979.

17. MA C.C.Y., IQBAL M. Statistical comparion of models for estimating solar radiation on inclined surfaces. Solar Energy, 31 (3), 313, 1983.

18. HU C. Modeling and evaluation of photovoltaic resources in Beijing and Shanghai. Journal of Shanghai University of Electric Power, 33 (06), 531, 2017.

19. ZHANG C., GAO G. A Rural Household Heating Method that Combines a Regenerative Electric Boiler with PV Power Generation. Polish Journal of Environmental Studies, 28 (5), 4001, 2019.

20. JÓZSEF B., TIHAMÉR T.S., BLANKA B. Evaluation of renewable energy sources in peripheral areas and renewable energy-based rural development. Renewable and Sustainable Energy Reviews, 90, 516, 2018.

21. LI Z.J., XUE A.C., BI T.S. On the characteristics of the predicted wind power based on three-parameter Weibull distribution. Control Conference (CCC), 2014.

22. HE Z.J. Rayleigh distribution correction formula and its application in wind energy calculation. Journal of Zhejiang Agricultural University, 02, 187, 1995.

23. MALCZYK T. Consistency of the Wind Power Industry, Including the Process of Sustainable Planning and Space Management. Polish Journal of Environmental Studies. 25 (2), 699, 2016. 
24. GUGLIANI G.K., SARKAR A., LEY C., MANDAL S. New methods to assess wind resources in terms of wind speed, load, power and direction. Renewable Energy, 129, 168, 2018.

25. LIU F., SUN F.B., LIU W.B., WANG T.T., WANG H., WANG X.M., LIM W.B. On wind speed pattern and energy potential in China. Applied Energy, 236, 867, 2019.

26. WANG S., XU J.X. Current situation and related issues of agricultural and forestry biomass power generation in China. Environmental protection, 23, 61, 2018.

27. ZUBERI M.J.S., HASANY S.Z., TARIQ M.A., FAHRIOGLU M. Assessment of biomass energy resources potential in Pakistan for power generation. International Conference on Power Engineering, Energy and Electrical Drives, Istanbul, 1301, 2013.

28. RECEBI Z., SELIMLI S., OZKAYMAK M., GONC O. Biogas Production from Animal Manure, Journal of Engineering Science and Technology, 10 (6), 722, 2015.

29. ZHU K.W., LIU Z., LU Z.C., PU G.Q., GUO W. Ecological potential and spatiotemporal analysis of biomass energy of major crops in China. China Agricultural Science, 48 (21), 4285, 2015.

30. KHAIRUDDIN N., ABD MANAF L., HASSAN M.A., WAN ABDUL KARIM GHANI W.A., HALIMOON N. Biogas Harvesting from Organic Fraction of Municipal Solid Waste as a Renewable Energy Resource in Malaysia: A Review. Polish Journal of Environmental Studies. 24 (4), 1477, 2015.

31. ZHANG T., BU M.D., GENG W. Pollution status and biogas potential of livestock manure in China. Journal of ecology, 31 (05), 1241, 2012.
32. WANG F.H., MA W.Q., DOU Z.X., MA L., LIU X.L., XU J.X., ZHANG F.S. Estimation of fecal production and environmental effects in China. China Environmental Science, 05, 614, 2006.

33. MA L., WANG F.H., MA W.Q., ZHANG F.S., FAN M.S. Estimation of the potential of medium- and longterm livestock manure and pollution in Northeast China. Journal of agricultural engineering, 08, 170, 2006.

34. FÜSUN BOYSAN, ÇIĞDEM ÖZER, KAĞAN BAKKALOĞLU, MUSTAFA TEKIN BÖREKÇI Biogas Production from Animal Manure, Procedia Earth and Planetary Science, 15, 908, 2015.

35. MITCHELL J.C., THEILACKER J.C., KLEIN S.A. Calculation of monthly average collector operating time and parasitic energy requirements. Solar Energy, 26 (6), 555, 1981.

36. BETZ A. Introduction to the Theory of Flow Machines. Oxford: Pergamon Press, 1966.

37. ZHANG F., BAI J.B., HAO Y.Z., ZHANG Z., JIANG M. The influence of surface ash of photovoltaic modules on their power generation performance. Power grid and clean energy, 28 (10), 82, 2012.

38. PENG C.Y., LUO H.L., KONG J. Research progress on estimation and utilization of crop straw resources in China. China Agricultural Resources and regionalization, 35 (03), 14, 2014.

39. LIU D.J., ZHANG X.H., RAO X.J. Comparative test of biogas production by dry fermentation of different crop straw. China biogas, 33 (04), 54, 2015.

40. ZHANG T., BU M.D., GENG W. Pollution status and biogas potential of livestock manure in China. Journal of ecology, 31 (05), 1241, 2012. 